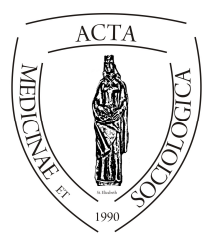

Acta Medicinae et

Sociologica (2019)

UNIVERSITY OF

DEBRECEN

Vol. 10. No. 29. (32-44)

FACULTY OF

HEALTH

doi:

NYÍREGYHÁZA

\title{
Foglalkoztatási helyzetkép \\ a telepi körülmények között élő nyíregyházi romák körében
}

\author{
R. Fedor Anita ${ }^{1}$, Balla Petra ${ }^{2}$ \\ ${ }^{1}$ föiskolai tanár, Debreceni Egyetem Egészségügyi Kar, Szociális és Társadalomtudományi Intézet, Társadalomtu- \\ dományi Tanszék. Nyíregyháza, Sóstói út 2-4. \\ ${ }^{2} \mathrm{PhD}$. hallgató, Debreceni Egyetem Gazdaságtudományi Kar, 4032 Debrecen, Böszörményi út 138.
}

\begin{tabular}{|c|c|}
\hline INFO & ABSTRACT \\
\hline $\begin{array}{l}\text { R. Fedor Anita } \\
\text { fedor.anita@foh.unideb.hu }\end{array}$ & \multirow{2}{*}{$\begin{array}{l}\text { Abstract. Situational picture of the employment of } \\
\text { Roma people residing in settlements in Nyíregyháza. } \\
\text { In our study we present the employment situation of peo- } \\
\text { ple residing in the Husar and Eastern settlements which } \\
\text { can be found in Nyíregyháza. This study is focussing on } \\
\text { one aspect from the many dimensions examined by the } \\
\text { research into the life quality of Roma people residing in } \\
\text { settlements. As expected, our results revealed that the } \\
\text { residents of these settlements are at a huge disadvantage } \\
\text { in employment. The extent of employment is mainly in- } \\
\text { fluenced by low education, the high number of children } \\
\text { and their attitude towards working. According to our } \\
\text { results, } 70 \% \text { of the respondents have been unemployed } \\
\text { before and } 49.8 \% \text { of them are unemployed at the moment. }\end{array}$} \\
\hline $\begin{array}{l}\text { Keywords } \\
\text { labour market, employ- } \\
\text { ment, Roma people, } \\
\text { settlement conditions, } \\
\text { multiple disadvantages }\end{array}$ & \\
\hline $\begin{array}{l}\text { Kulcsszavak: } \\
\text { munkaerőpiac, foglal- } \\
\text { koztatás, romák, telepi } \\
\text { körülmények, halmozott } \\
\text { hátrány }\end{array}$ & $\begin{array}{l}\text { Absztrakt. Elemző munkánkban a Nyíregyházán találha- } \\
\text { tó Huszártelep és Keleti lakótelep lakóinak foglalkoztatá- } \\
\text { si helyzetét mutatjuk be. A tanulmány a szegregátumok } \\
\text { lakóit (romák) fókuszba állító, az életminőség több di- } \\
\text { menzióját feltérképező vizsgálat egyetlen szegmensére a } \\
\text { munkaerőpiaci helyzetre koncentrál. Eredményeink a } \\
\text { vártnak megfelelóen a telepi lakosok óriási foglalkoztatá- } \\
\text { si hátrányáról árulkodnak, melynek mctértékét nagyban } \\
\text { befolyásolja az iskolázottság alacsony szintje, a magas } \\
\text { gyerekszám és a munkavégzéshez kötődő attitűd. Ered- } \\
\text { ményeink szerint a válaszadók } 70 \% \text {-a volt már munka- } \\
\text { nélküli eddigi élete során, s } 49,8 \% \text {-uk jelenleg is. }\end{array}$ \\
\hline
\end{tabular}

Ez a tanulmány a TOP-6.9.1-16-NY1-2017-00001 azonosító számú

"Közösen a kiútért" címü projekt támogatásával készült. 


\section{Bevezetés}

Tanulmányunkban Nyíregyháza városában található két szegregátum lakóinak munkaerőpiaci jellemzőit tárjuk fel. Elemző munkánkban egy általános munkaerőpiaci felvezető után a foglalkoztatás egyes mutatóinak bemutatásánál a Huszár és Keleti telepi két almintát egyben, majd külön-külön kezelve, valamint a 2018-as nyíregyházi lakosok körében lebonyolított adatfelvétel eredményeivel összevetve is prezentáljuk.

A foglalkoztatási helyzetet felmérő kérdésblokk összesen 19 kérdést tartalmazott, melyek között voltak nyitott és zártkérdések, valamint egy ötfokú Likert-skála. Az adatok kiértékeléséhez az SPSS 24.00 for Windows szoftvert használtunk, ezen belül egy- és többváltozós elemzési technikákat alkalmaztunk. Az elemzés során a leggyakrabban használt többváltozós elemzési formák közé tartozott a kereszttáblaelemzés. A két változó közötti összefüggés bemutatására a Pearson-féle $\chi^{2}$ statisztikát alkalmaztunk.

\section{A roma foglalkoztatás általános jellemzői}

A munkaképes népesség munkaerőpiaci potenciálját alapvetően meghatározza egy térség, vagy szükebb értelemben az adott lakókörnyezet hátrányos volta, a perifériális helyzet számos negatívuma. A hátrányos helyzet meghatározásának számos lehetősége van, függ ez attól, hogy milyen szempontból közelítjük meg. A foglalkoztatáspolitika aspektusából történő megvilágításból: halmozottan hátrányos helyzetű az, akinek a munkaerőpiaci esélyei, lehetőségei az átlagosnál rosszabbak. Közelebb kerülünk a valósághoz, ha az okokat és a jellemzőket mérlegeljük. A munkaerőpiacon jelentkező hátrányos megkülönböztetés okai között lehet a nem, a nemzetiségi, etnikai, a kor vagy a vallás, esetleg a fogyatékosság miatti kirekesztés. A kistelepüléseken élö roma közösségekben ezekhez társulhat még a nagycsalád, a gyakori munkanélküliség, az elöítélet és az átlagnál is nagyobb arányú iskolázatlanság. Ez az állapot - különösen, ha tartós - egyre mélyebb szegénységbe taszítja az itt élőket. (Láczay, R. Fedor é.n.)

Az iskolai végzettség alacsony szintje, a szakképzettség hiánya, a roma etnikumhoz tartozás, nehezíti a munkaerőpiaci helytállást, mely tartós munkanélküliséget, jövedelmi szegénységet végső esetben kirekesztődést eredményezhet. A roma családokat ezen elhelyezkedést gátló tényezők szinte mindegyike jellemzi. A helyzetet tovább rontja a keleti határmentiség. A roma népesség 52\%-a a legkedvezőtlenebb foglalkoztatási mutatókkal rendelkező Észak-magyarországi, Észak-alföldi régióban él. A két régió közül is kiemelkedik az Észak-alföldi régió (1. táblázat) és ezen belül Szabolcs-Szatmár-Bereg megye hátránya (1. ábra). A 2003-as és 2004-es megyei kutatások eredményei azt mutatják, hogy a háztartásfők fele fejezte be az általános iskolát, négytizedének nincs általános iskolai végzettsége sem, 6,3 százaléka szakmunkás végzettségü, 1,8 százaléka érettségizett, és 0,2 százalék diplomás (Fónai, Pénzes 2006:81). Ezek a számok jelentős mértékben magyarázzák a romák foglalkoztatásának a helyzetét. 


\begin{tabular}{|c|c|c|c|c|c|c|}
\hline & \multicolumn{2}{|c|}{$\mathbf{2 0 1 4}$} & \multicolumn{2}{c|}{$\mathbf{2 0 1 6}$} & \multicolumn{2}{c|}{$\mathbf{2 0 1 8}$} \\
\cline { 2 - 7 } & $\begin{array}{c}\text { Munka- } \\
\text { nélküli- } \\
\text { ségi ráta } \\
\%\end{array}$ & $\begin{array}{c}\text { Foglal- } \\
\text { kozta-tási } \\
\text { ráta \% }\end{array}$ & $\begin{array}{c}\text { Munka- } \\
\text { nélküli- } \\
\text { ségi ráta } \\
\%\end{array}$ & $\begin{array}{c}\text { Foglalkozta- } \\
\text { tási ráta \% }\end{array}$ & $\begin{array}{c}\text { Munkanél- } \\
\text { küliségi } \\
\text { ráta \% }\end{array}$ & $\begin{array}{c}\text { kozta- } \\
\text { tási ráta } \\
\%\end{array}$ \\
\hline $\begin{array}{c}\text { Közép- } \\
\text { Magyarország }\end{array}$ & 6,2 & 66 & 3,9 & 70,8 & 2,8 & 72,0 \\
\hline $\begin{array}{c}\text { Közép- } \\
\text { Dunántúl }\end{array}$ & 5,6 & 64,3 & 3 & 68,4 & 2,2 & 70,9 \\
\hline $\begin{array}{c}\text { Nyugat- } \\
\text { Dunántúl }\end{array}$ & 4,6 & 65,8 & 2,7 & 68,9 & 2,0 & 73,0 \\
\hline Dél-Dunántúl & 7,9 & 58,6 & 6,2 & 62,2 & 5,6 & 64,5 \\
\hline $\begin{array}{c}\text { Észak- } \\
\text { Magyarország }\end{array}$ & 10,5 & 55,7 & 6,3 & 61,8 & 4,8 & 65,6 \\
\hline Észak-Alföld & $\mathbf{1 1 , 9}$ & $\mathbf{5 7 , 3}$ & $\mathbf{9 , 3}$ & $\mathbf{6 2}$ & $\mathbf{6 , 7}$ & $\mathbf{6 5 , 7}$ \\
\hline Dél-Alföld & 9 & 59,7 & 5,6 & 65,7 & 3,4 & 68,8 \\
\hline
\end{tabular}

Forrás: saját szerkesztés, KSH alapján:

https://www.ksh.hu/docs/hun/xstadat/xstadat_eves/i_qlf031.html

1. táblázat: A 15-64 éves népesség gazdasági aktivitása

A munkanélküliségi adatokat tekintve azt látjuk, hogy az országosan mért 3,4\%-hoz képest a regionális mutató 3,3\%-kal magasabb. A régió belső munkanélküliségi struktúráját vizsgálva azt látjuk, hogy Jász-Nagykun-Szolnok megye mutatója $(4,7 \%)$ csak kevéssé haladja meg az országos szintet, viszont a magát regionális szinten legrosszabbul pozícionáló Szabolcs-Szatmár-Bereg megye több mint kétszeres munkanélküliségi rátája $(8,9 \%)$ országos viszonylatban is a legmagasabb.

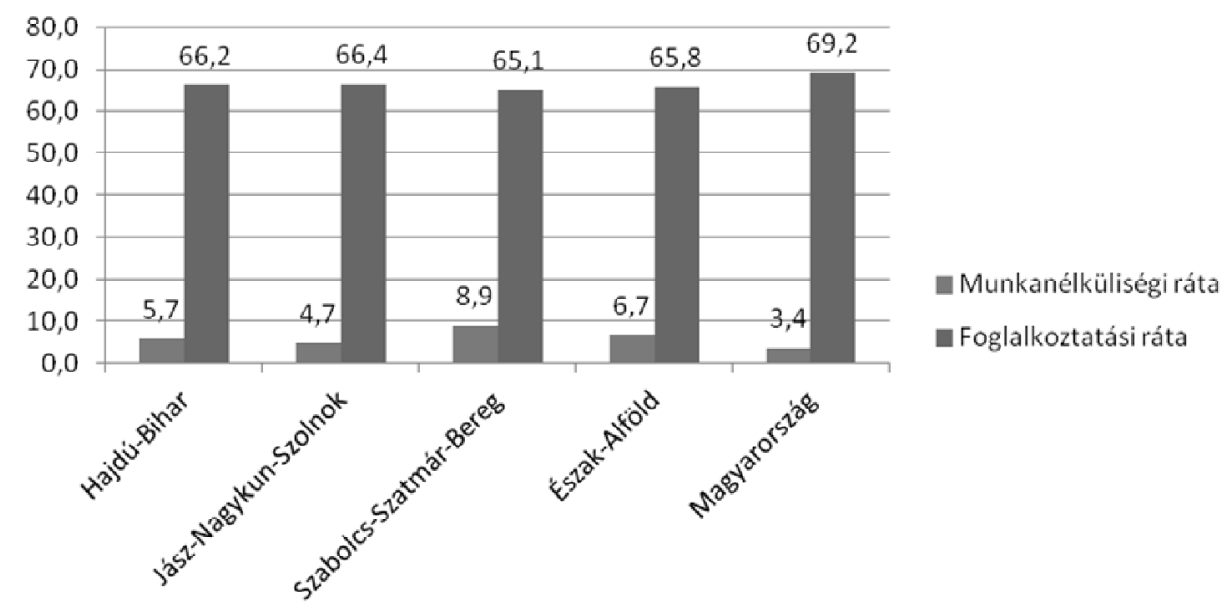

Forrás: saját szerkesztés https://www.ksh.hu/docs/hun/xstadat/xstadat_eves/i_qlf031.html

1. ábra: Az Észak-alföldi régió megyéinek mutatói, 15-64 évesek (\%) 2018 
A legfrissebb adatok szerint, a korábbi éveknek megfelelően a romák foglalkoztatása jóval elmarad a nem roma népességhez képest. Körükben 23,9\%-kal dolgoztak kevesebben és $14,7 \%$-kal többüket érintette a munkanélküliség, mint a többségi társadalom tagjait. Bár az is igaz, hogy 2014 és 2017 között a foglalkoztatási helyzetükben javulás tapasztalható: a foglalkoztatottak aránya 11,6\%-kal nőtt, az inaktívak aránya pedig közel ennyivel csökkent. Ez a közfoglalkoztatásban való magasabb részvételükkel magyarázható. A foglalkoztatottak csoportján belül a roma közfoglalkoztatottak aránya $41,8 \%$ a nem romáké 4,2\% volt. (KSH, 2018) (Láczay, R. Fedor é.n.) (2. táblázat)

\begin{tabular}{|c|c|c|c|c|}
\hline & \multicolumn{2}{|c|}{$\mathbf{2 0 1 4}$} & \multicolumn{2}{c|}{$\mathbf{2 0 1 7}$} \\
\cline { 2 - 5 } & Romák & Nem romák & Romák & $\begin{array}{c}\text { Nem ro- } \\
\text { mák }\end{array}$ \\
\hline Foglalkoztatottak & 33,4 & 62,8 & 45,0 & 68,9 \\
\hline Férfiak foglakoztatási rátája & 42,2 & 68,6 & 54,6 & 75,9 \\
\hline Nök foglakoztatási rátája & 25,1 & 57,1 & 35,9 & 62,1 \\
\hline Munkanélküliségi ráta & 30,1 & 6,8 & 18,5 & 3,8 \\
\hline $\begin{array}{c}\text { Tartós munkanélküliek ará- } \\
\text { nya }\end{array}$ & 53,9 & 57,2 & 38,0 & 41,0 \\
\hline $\begin{array}{c}\text { Korai iskolaelhagyók (18-24 } \\
\text { éves) }\end{array}$ & 57,0 & 10,3 & 65,3 & 9,4 \\
\hline $\begin{array}{c}\text { NEET (nem tanul, nem dol- } \\
\text { gozik) }\end{array}$ & 38,2 & 12,7 & 38,2 & 9,4 \\
\hline
\end{tabular}

Forrás: KSH. MEF.

http://www.ksh.hu/docs/hun/xftp/idoszaki/munkerohelyz/munkerohelyz17.pdf

2. táblázat: A 15-64 éves népesség megoszlása gazdasági aktivitás szerint 2014, 2017

A munkaerőpiacon megjelenő általános egyenlőtlenségek hangsúlyosabban jelennek meg az egyébként is hátrányos helyzetü roma munkavállalói csoportoknál. A nők munkaerőpiaci hátránya jelentősebb a nem roma nőkéhez képest. A nők alacsonyabb foglalkoztatási szintjét magyarázza a magas gyermekszám valamint a nemi szerepekhez kapcsolódó kulturális hatások is. Míg a nem roma nők foglalkoztatási rátája $62,1 \%$, addig a romáké mindössze $35,9 \%$. Az is igaz, hogy a roma nők foglalkoztatási színvonala több mint 10\%-kal nőtt 2014 és 2017 között.

Szintén a kulturális mássággal, a család által közvetített értékekkel, magatartásformákkal és a lehetőségek hiányával magyarázható, hogy a 18-24 éves legfeljebb alapfokú végzettséggel rendelkező korai iskolaelhagyók aránya 65,3\%. Az iskolaelhagyók között ún. NEET-fiatalok (15-24 évesek, akik nem dolgoznak, és sem iskolarendszerü, sem iskolarendszeren kívüli oktatásban nem vesznek részt) aránya $38,2 \%$, mely messze meghaladja a nem roma társadalomban jelenlévő arányokat, ahol ezek mindkét esetben 9,4\%-ot mutatnak. A munkahelybiztonság a kiszámíthatóság és az előretervezhetőség szempontjából kedvezőtlen határozott, rövid idejü munkaszerződés is jobban érinti a roma $(50,5 \%)$, mint a nem roma $(9,2 \%)$ munkavállalókat. 
Lassan a negyedik, szüleik, nagyszüleik elődleges munkaerőpiaci jelenlétet meg nem tapasztaló generáció nő fel. Így az érintett családok hátránya nemzetékrőlnemzedékre öröklödik.

A fentebb bemutatott bizonytalan munkaerőpiaci jellemzőket ún. prekár jellemzőkként definiáljuk, melyek közül egyik-másik valamennyi társadalmi réteg életében jelen lehet, de az általános bizonytalanságként definiált prekár tényezők halmozódása egyik társadalmi csoportnál sem olyan erős, mint a romáknál. (R. Fedor és Fónai, 2017)

\section{A telepi körülmények között élő nyíregyházi romák foglalkoztatási helyzete}

Továbbiakban Nyíregyháza két szegregátumában - a Huszártelepen és a Keleti lakótelepen - lebonyolított empirikus vizsgálat eredményeit mutatjuk be a foglalkoztatási helyzetre koncentrálva.

A két telepen élő válaszadók egynegyede $(24,4 \%)$ keresett a megkérdezés pillanatában munkát. Vélhetően ők azok, akik munka nélkül vannak, illetve akik valamilyen ok miatt munkahelyváltáson gondolkodnak. A két telep lakóinak véleménynyilvánítása szinte teljes mértékben egybecseng erről a kérdésről; a Huszártelepen élők 24,5\%-a, míg a Keleti lakótelepen élők 24,3\%-a várt munkára.

Kíváncsiak voltunk arra is, hogy a munkát nem keresők attitüdjét milyen tényezők magyarázzák. Ehhez kapcsolódóan az általunk megjelölt 11 lehetséges ok közül kellett kiválasztaniuk az érintetteknek a rájuk leginkább jellemzőt.

\begin{tabular}{|l|c|c|}
\hline \multicolumn{1}{|c|}{ Okok } & Említi & Nem említi \\
\hline $\begin{array}{l}\text { mert van munkája, meg van vele elé- } \\
\text { gedve }\end{array}$ & 39,8 & 60,2 \\
\hline úgysem talál a környéken & 6,6 & 93,4 \\
\hline úgysem talál megfelelöt & 7,1 & 92,9 \\
\hline úgysem talál olyat, amelyik jól fizet & 8,1 & 91,9 \\
\hline gyereket szeretne vállalni & 2,5 & 97,5 \\
\hline el szeretne költözni & 8,1 & 91,9 \\
\hline más családi okokból & 11,1 & 88,9 \\
\hline tanulnia kell még, átképeznie magát & 5,1 & 94,9 \\
\hline jelenleg is tanul & 1,5 & 98,5 \\
\hline $\begin{array}{l}\text { alkalmi munkái, bejelentetlen munkája } \\
\text { így is van, nem akar keresni }\end{array}$ & 9,1 & 90,9 \\
\hline egyéb ok & 30,5 & 69,5 \\
\hline
\end{tabular}

Forrás: Telepi kutatás 2019.

3. táblázat: Miért nem keres munkát? (\%) $(\mathrm{N}=271)$

A 3. táblázat adataiból kiolvasható, hogy azok, akik nem kerestek munkát, ezt azzal magyarázták a legnagyobb arányban, hogy jelenleg van munkájuk és elégedettek is vele (39,8\%). A második legtöbbek által megjelölt tényező az egyéb okok csoportjá- 
ba tartozott. Az egyéb kategóriát megjelölők körében az egészségi állapot, a nyugdíjas kor, a gyermekgondozási szabadság, valamint az inaktivitás egyéb formái voltak a legfőbb magyarázó tényezők.

A két telep lakóinak válaszait összehasonlítva nem tapasztaltunk jelentős különbséget. A függetlenségvizsgálat is csak két tényező esetében jelzett statisztikailag mérhető különbséget: „el szeretne költözni” és az „,alkalmi munkái, bejelentetlen munkája így is van” kategóriák vonatkozásában. (4. táblázat)

Az adatotokból kitünik, hogy a Huszártelep lakói valamivel nagyobb arányban keresnek munkát, azonban az is látható, hogy borúlátóbbak a munkakeresés sikerességét illetően. Az itt élők körében magasabb volt az erre vonatkozó kijelentést megjelölök aránya: „úgysem talál a környéken”, , úgysem talál megfelelöt”, „,úgysem talál olyat, amelyik jól fizet”. Ezzel összefüggésben az tapasztalható, hogy talán éppen ezen okok miatt nyitottabbak a helyzetük javítását nagyobb valószínüséggel eredményező költözésre és tanulásra.

\begin{tabular}{|l|c|c|c|}
\hline \multicolumn{1}{|c|}{ Okok } & \multicolumn{1}{|c|}{$\begin{array}{c}\text { Huszár lakótelep } \\
\text { (N=145) } \\
\text { említések gyakorisága }\end{array}$} & $\begin{array}{c}\text { Keleti lakótelep } \\
\text { (N=53) említések } \\
\text { gyakorisága }\end{array}$ & $\begin{array}{c}\text { Pearson } \\
\text { Chi-Square }\end{array}$ \\
\hline $\begin{array}{l}\text { mert van munkája, meg } \\
\text { van vele elégedve }\end{array}$ & 41,2 & 35,8 & $\mathrm{p}=0,495$ \\
\hline $\begin{array}{l}\text { úgysem talál a környé- } \\
\text { ken }\end{array}$ & 7,6 & 3,8 & $\mathrm{p}=0,338$ \\
\hline úgysem talál megfelelöt & 7,6 & 5,7 & $\mathrm{p}=0,640$ \\
\hline $\begin{array}{l}\text { úgysem talál olyat, ame- } \\
\text { lyik jól fizet }\end{array}$ & 9,7 & 3,8 & $\mathrm{p}=0,179$ \\
\hline $\begin{array}{l}\text { gyereket szeretne vállal- } \\
\text { ni }\end{array}$ & 3,4 & 0,0 & $\mathrm{p}=0,171$ \\
\hline el szeretne költözni & 11,0 & 0,0 & $\mathbf{p}=\mathbf{0 , 0 1 2}$ \\
\hline más családi okokból & 19,0 & 3,0 & $\mathrm{p}=0,140$ \\
\hline $\begin{array}{l}\text { tanulnia kell még, átké- } \\
\text { peznie magát }\end{array}$ & 6,2 & 1,9 & $\mathrm{p}=0,219$ \\
\hline jelenleg is tanul & 2,1 & 0,0 & $\mathrm{p}=0,291$ \\
\hline $\begin{array}{l}\text { alkalmi munkái, bejelen- } \\
\text { tetlen munkája így is } \\
\text { van, nem akar keresni }\end{array}$ & 11,7 & 1,9 & $\mathbf{p}=\mathbf{0 , 0 3 3}$ \\
\hline egyéb ok & 28,5 & 35,8 & $\mathrm{p}=0,318$ \\
\hline
\end{tabular}

Forrás: Telepi kutatás 2019. , R. Fedor 2019., Nyíregyháza Életminősége 2018.

4. táblázat: Miért nem keres munkát? (\%)

A munkát keresők többsége (59,8\%) úgy véli, hogy fél éven belül el tud majd helyezkedni, 17,5\% szerint ehhez több mint hat hónapra lesz szükség, míg a válaszadók egynegyede $(25,5 \%)$ igen pesszimistán gondolkodik a kérdésröl, mely szerint egyáltalán nem fog tudni elhelyezkedni. (5. táblázat) 


\begin{tabular}{|c|c|c|c|}
\hline Időtartam & $\begin{array}{c}\text { Huszár } \\
\text { lakótelep }\end{array}$ & Keleti lakótelep & $\begin{array}{c}\text { Két telep együtt } \\
\text { (N=102) }\end{array}$ \\
\hline 2 héten belül & 9,2 & 7,7 & 8,8 \\
\hline 3-4 héten belül & 7,9 & 19,2 & 10,8 \\
\hline 1-2 hónapon belül & 14,5 & $\mathbf{2 3 , 1}$ & 16,7 \\
\hline 3-4 hónapon belül & 10,5 & 7,7 & 9,8 \\
\hline 5-6 hónapon belül & 14,5 & 11,5 & 13,7 \\
\hline ennél hosszabb időn belül & $\mathbf{1 5 , 8}$ & 11,5 & 14,7 \\
\hline $\begin{array}{c}\text { nem fog tudni elhelyez- } \\
\text { kedni }\end{array}$ & $\mathbf{2 7 , 6}$ & 19,2 & 25,5 \\
\hline Összesen & 100,0 & 100,0 & 100,0 \\
\hline
\end{tabular}

Forrás: Telepi kutatás 2019. , R. Fedor 2019., Nyirregyháza Életminösége 2018.

5. táblázat: Mit gondol, mennyi idő múlva fog tudni elhelyezkedni? (\%) p=0,640

A két telep lakóinak erre vonatkozó véleménye szintén a huszártelepiek pesszimizmusát mutatja. Körükben többen gondolkoznak úgy, hogy több mint hat hónap után vagy egyáltalán nem fognak munkát találni.

A két telepen élő foglalkoztatott romák egyharmadára az általánosnak tekinthető heti 40 órás foglalkoztatás jellemző. Ez messze elmarad a Nyíregyháza Életminősége vizsgálatban részt vevő nyíregyházi lakosokhoz képest, ahol a heti 40 órában foglalkoztatottak aránya 76,3\%-os. Ennél alacsonyabb munkaóra 25,5\%-ukat, míg ennél magasabb 10,8\%-ukat érinti. A telepi lakosok egyharmada közmunkaprogram keretében dolgozik. A Huszártelepen jellemzőbb a részmunkaidős foglalkoztatás, míg a határozott munkaidejü szerződéssel történő fogalakoztatás a Keleti lakótelepen élők körében gyakoribb. A legtöbben 6 hónapra és egy éves időtartamra szóló szerződéssel vannak foglalkoztatva. (6. 7. és 8. táblázatok)

\begin{tabular}{|l|c|c|}
\hline & $\begin{array}{c}\text { Telepi vizsgálat } \\
\text { (N=112) }\end{array}$ & $\begin{array}{c}\text { Nyíregyháza } \\
\text { Életminősége } \\
\text { (N=322) }\end{array}$ \\
\hline $\begin{array}{l}\text { Folyamatos, normál foglalkoztatás (napi } \\
8 \text { óra, heti 40 óra, kinevezéssel) }\end{array}$ & $\mathbf{3 1 , 3}$ & $\mathbf{7 6 , 3}$ \\
\hline Meghatározott időre szóló szerződéssel & $\mathbf{1 7 , 9}$ & $\mathbf{8 , 1}$ \\
\hline Részmunkaidőben & 5,4 & 5,5 \\
\hline Közmunka program keretében & $\mathbf{2 8 , 6}$ & $\mathbf{1 , 9}$ \\
\hline Alkalmi munka, szerződés nélkül & $\mathbf{1 1 , 6}$ & $\mathbf{2 , 3}$ \\
\hline Egyéb & 5,2 & 5,8 \\
\hline
\end{tabular}

Forrás: Telepi kutatás 2019. , R. Fedor 2019., Nyirregyháza Életminősége 2018.

6. táblázat: Milyen módon foglalkoztatják Önt? (\%) 


\begin{tabular}{|l|c|c|}
\hline & Huszár lakótelep & Keleti lakótelep \\
\hline $\begin{array}{l}\text { Folyamatos, normál foglalkoztatás (napi } 8 \\
\text { óra, heti 40 óra, kinevezéssel) }\end{array}$ & 30,3 & 34,8 \\
\hline Meghatározott időre szóló szerződéssel & $\mathbf{1 2 , 4}$ & $\mathbf{3 9 , 1}$ \\
\hline Részmunkaidőben & 6,7 & 0,0 \\
\hline Közmunka program keretében & $\mathbf{3 1 , 5}$ & $\mathbf{1 7 , 4}$ \\
\hline Alkalmi munka, szerződés nélkül & 12,4 & 8,7 \\
\hline Egyéb & 6,7 & 0,0 \\
\hline
\end{tabular}

Forrás: Telepi kutatás 2019.

7. táblázat: Milyen módon foglalkoztatják Önt? (\%) N=112; p=0,034

\begin{tabular}{|c|c|c|}
\hline Időtartam & Telepi vizsgálat & Nyíregyháza Életminősége \\
\hline kevesebb, mint 6 hónapra & 8,6 & 12,6 \\
\hline 6 hónap-1 év közötti időre & $\mathbf{6 4 , 3}$ & $\mathbf{1 2 , 6}$ \\
\hline 1 évre & 15,7 & 15,2 \\
\hline 1-2 év között & 1,4 & 6,6 \\
\hline 2-5 év között & n.a. & 19,2 \\
\hline 5 évnél hosszabb & $\mathbf{1 0 , 0}$ & $\mathbf{3 3 , 8}$ \\
\hline Összesen & $\mathbf{1 0 0 , 0}$ & $\mathbf{1 0 0 , 0}$ \\
\hline
\end{tabular}

Forrás: Telepi kutatás 2019. , R. Fedor 2019., Nyirregyháza Eletminösége 2018.

8. táblázat: Amennyiben Ön szerződéssel dolgozik, kérjük, nevezze meg, milyen időtartamra kötöttek Önnel szerződést! (\%) (N=221)

A telepi válaszadók jelentős részének van/volt már munkatapasztalata. 77,4\%-uk mondta azt, hogy korábban dolgozott. A két lakótelep között nem találtunk jelentős eltérést ebben a kérdésben. A megkérdezettek 63,7\%-ának legfeljebb három munkahelye volt eddig, minden negyedik $(25,5 \%)$ érintett nyilatkozta azt, hogy 4-6 munkahelyen dolgozott. 10,8\%-a ennél több, akár 10 munkahelyen is dolgozott eddigi élete során.

A jelenlegi gazdasági aktivitás megállapítását az „,Amennyiben nem dolgozik - mi ennek az oka" kérdéssel mértük fel. A válaszadók választhattak a munkával valamint a személyes okokkal kapcsolatos lehetőségek között. A munkával kapcsolatos okokból a tényleges munkanélküliségre következtethetünk, míg a személyes okokból történő munkátlanság az inaktivitás egyéb formáit rejti magában. Eredményeink szerint a telepi lakók 20\%-a (53 fó) munkával kapcsolatos okok miatt nem dolgozott a megkérdezés idején, vagyis munkanélküli volt. Még rosszabba a helyzet, ha a , GYED/GYES/GYET (nincs munkahelye)” kategóriát választó 31 föt is beleszámoljuk a munkanélküliekbe, hiszen saját bevallásuk szerint ők a gyermekgondozás előtt nem végeztek fizette munkát, vagyis munka nélkül voltak. Így 
számolva a munkavállalási gondokkal küzdők arány meghaladja a 30\%-ot (31,6\%), amely többszöröse a Nyíregyháza Életminősége vizsgálatban mért 4,6\%os aránynak. A 9. táblázat adatai a telepi lakosok óriási hátrányáról árulkodnak. Érdemes azt is kiemelni, hogy a rokkantságból eredő munkaerőpiaci távolmaradás nagyságrendekkel nagyobb mértékben érinti a telepi lakosokat, a teljes minta 12\%a az inaktivitás ezen formája miatt nem dolgozik. Ez az arány a Nyíregyháza Életminősége vizsgálatban 2,2\% (!). Kiemelt jelentőséggel bír a jó egészségi státusz is a munkaerőpiaci stabil jelenlét szempontjából. A lakosság egészségi állapotának javításával, az egyenlőtlenségek csökkentésével elősegíthető a fejlődés, fokozható a gazdasági aktivitás ami pozitív hatást eredményezhet a társadalomban (Jávorné, 2016).

\begin{tabular}{|c|c|c|}
\hline Munkával kapcsolatos okok & Telepi vizsgálat & $\begin{array}{c}\text { Nyíregyháza Életminősége } \\
\text { vizsgálat }\end{array}$ \\
\hline Elbocsájtottak & 9 & 6 \\
\hline Lejárt a szerződésem & 44 & 14 \\
\hline Tönkrement a vállalkozásom & 0 & 3 \\
\hline Személyes okok & Telepi vizsgálat & $\begin{array}{c}\text { Nyíregyháza Életminősége } \\
\text { vizsgálat }\end{array}$ \\
\hline $\begin{array}{l}\text { GYED/GYES/GYET } \\
\text { (van munkahelye) }\end{array}$ & 9 & 8 \\
\hline $\begin{array}{l}\text { GYED/GYES/GYET } \\
\text { (nincs munkahelye) }\end{array}$ & 31 & 3 \\
\hline $\begin{array}{l}\text { Beteg, fogyatékos személy } \\
\text { ápolása }\end{array}$ & 4 & 3 \\
\hline Költözés & 1 & 4 \\
\hline Tanulmányok folytatása & 5 & 24 \\
\hline $\begin{array}{l}\text { Saját betegség, fogyatékosság, } \\
\text { rokkantság }\end{array}$ & 32 & 11 \\
\hline Nyugdíj & 17 & 87 \\
\hline Egyéb & 19 & 23 \\
\hline Összesen & 171 & 186 \\
\hline
\end{tabular}

Forrás: Telepi kutatás 2019. , R. Fedor 2019., Nyíregyháza Életminösége 2018.

9. táblázat: Jelenleg nem dolgozom választ megjelölők száma (fö) (N=171; 186)

A telepi körülmények között élők kedvezőtlen munkaerőpiaci helyzetét erősíti, hogy a megkérdezettek több mint 70\%-a volt már munkanélküli, s 49,8\%-uk jelenleg is az. Ehhez képest a Nyíregyháza Életminősége vizsgálatban részvevők 35,7\%-a tapasztalta már meg a munkanélküliséget és a vizsgálat időpontjában (2018) 4,6\% volt munkanélküli. Ehhez szorosan kapcsolódik a közfoglalkoztatással érintettek arányában tapasztalható különbség. A telepi lakosok 58,3\%-a dolgozott már közmunkásként, s minden harmadik válaszadó jelenleg is ilyen módon dolgozik. Ezzel szemben a Nyíregyháza Életminősége vizsgálatban résztvevők $6,7 \%$-a volt már közfoglalkoztatott, s a megkérdezés pillanatában mindössze 2,4\%-uk vett rész közmunka programban. (10. táblázat) 


\begin{tabular}{|c|c|c|}
\hline $\begin{array}{c}\text { Volt-e regisztrált munkanélküli eddigi élete } \\
\text { során? N=465 }\end{array}$ & $\begin{array}{c}\text { Telepi } \\
\text { vizsgálat }\end{array}$ & $\begin{array}{c}\text { Nyíregyháza } \\
\text { Életminösége vizsgálat }\end{array}$ \\
\hline igen, jelenleg is az & 21,2 & 4,6 \\
\hline igen, de jelenleg nem az & 49,8 & 31,1 \\
\hline nem & 29,0 & 64,3 \\
\hline Vett-e már részt közmunka programban? & $\begin{array}{c}\text { Telepi } \\
\text { vizsgálat }\end{array}$ & $\begin{array}{c}\text { Nyíregyháza } \\
\text { Életminösége vizsgálat }\end{array}$ \\
\hline igen, jelenleg is abban dolgozik & 15,6 & 2,4 \\
\hline igen, de jelenleg nem abban dolgozik & 42,7 & 4,3 \\
\hline nem & 41,6 & 93,3 \\
\hline
\end{tabular}

Forrás: Telepi kutatás 2019. , R. Fedor 2019., Nyíregyháza Életminösége, 2018.

10. táblázat: Munkanélküliséggel, közmunkával kapcsolatos információk (\%)

A telepen élök átlagosan 9 hónapot töltöttek munkanélküliként, átlagosan 4,5 alkalommal vettek részt közmunkaprogramban, melynek hossza 19,8 hónapra terjedt ki átlagosan.

\begin{tabular}{|c|c|c|}
\hline Elégedettség mértéke & $\begin{array}{c}\text { Telepi vizsgálat } \\
\mathbf{N}=\mathbf{1 7 7}\end{array}$ & $\begin{array}{c}\text { Nyíregyháza Életminő- } \\
\text { sége vizsgálat } \mathbf{N = 3 7 3}\end{array}$ \\
\hline egyáltalán nem elégedett & $\mathbf{3 1 , 1}$ & $\mathbf{1 1 , 2}$ \\
\hline nem elégedett & $\mathbf{2 2 , 6}$ & $\mathbf{1 5 , 0}$ \\
\hline elégedett is és nem is & 28,8 & 30,0 \\
\hline elégedett & 12,4 & 31,3 \\
\hline teljes mértékben elégedett & 5,1 & 12,5 \\
\hline
\end{tabular}

Forrás: Telepi kutatás 2019. , R. Fedor 2019., Nyirregyháza Életminősége 2018.

11. táblázat: Mennyire elégedett Ön jelenlegi fizetésével, jövedelemével? (\%)

A telepi vizsgálatban részvevők több mint fele "elégedetlen” illetve „egyáltalán nem elégedett" a fizetésével (kétszer annyian, mint a nyíregyházi lakosok). (11. táblázat) Ez nem meglepő a foglalkoztatásukra vonatkozó adatok tükrében. A magas munkanélküliség és a közfoglalkoztatásban dolgozók nagy aránya jelentősen meghatozza az itt élők jövedelmi szintjét. A telepi lakosok átlagjövedelem messze elmarad a Nyíregyháza Életminősége vizsgálatban részvevő lakókétól. Előbbiek meghatározó aránya $(76,7 \%)$ az alsó két jövedelmi decilisbe tartozik. (Fábián, Takács, 2018; Fábián és mtsai, 2018)

\begin{tabular}{|c|c|c|}
\hline Elégedettség mértéke & $\begin{array}{c}\text { Telepi vizsgálat } \\
\mathbf{N}=\mathbf{1 3 3}\end{array}$ & $\begin{array}{c}\text { Nyíregyháza Életminő- } \\
\text { sége vizsgálat } \mathbf{N = 3 5 4}\end{array}$ \\
\hline egyáltalán nem elégedett & 12,8 & 3,9 \\
\hline nem elégedett & 18,7 & 9,0 \\
\hline elégedett is és nem is & 27,1 & 27,0 \\
\hline elégedett & 27,1 & 39,1 \\
\hline teljes mértékben elégedett & 14,3 & 21,1 \\
\hline
\end{tabular}

Forrás: Telepi kutatás 2019. , R. Fedor 2019., Nyirregyháza Életminösége 2018.

12. táblázat. Mennyire elégedett Ön a munkavégzés körülményeivel? (\%) N=354 
A munkavégzés körülményeiről alkotott vélemények is jelentősen különböznek a telepi és a nyíregyházi vizsgálat tekintetében. Míg a nyíregyházi vizsgálatban részvevők 60,2\%-a tarozik az „elégedettek” és a „teljes mértékben elégedettek” táborába, addig a telepi lakosok 41,4\%-a gondolkodik pozitívan erről a kérdésről. (12. táblázat)

\begin{tabular}{|c|c|c|}
\hline Elégedettség mértéke & Telepi vizsgálat $\mathrm{N}=134$ & $\begin{array}{l}\text { Nyíregyháza Életminő- } \\
\text { sége vizsgálat } N=353\end{array}$ \\
\hline egyáltalán nem elégedett & 10,4 & 2,5 \\
\hline nem elégedett & 11,2 & 9,2 \\
\hline elégedett is és nem is & 23,2 & 21,2 \\
\hline elégedett & 35,8 & 37,8 \\
\hline teljes mértékben elégedett & 19,4 & 29,3 \\
\hline \multicolumn{3}{|c|}{ Mennyire elégedett Ön a munka típusával? (\%) $\mathbf{N}=353$} \\
\hline Elégedettség mértéke & Telepi vizsgálat $\mathrm{N}=134$ & $\begin{array}{l}\text { Nyíregyháza Életminő- } \\
\text { sége vizsgálat } \mathbf{N}=\mathbf{3 5 3}\end{array}$ \\
\hline egyáltalán nem elégedett & 11,9 & 3,9 \\
\hline nem elégedett & 13,5 & 6,3 \\
\hline elégedett is és nem is & 27,6 & 20,4 \\
\hline elégedett & 31,3 & 36,1 \\
\hline teljes mértékben elégedett & 15,7 & 33,3 \\
\hline
\end{tabular}

Forrás: Telepi kutatás 2019. , R. Fedor 2019., Nyíregyháza Életminösége 2018.

13. táblázat. Mennyire elégedett Ön a munkaidő beosztásával és a munka típusával? (\%) $\mathrm{N}=353$

A telepiek munkaidő beosztásával és a végzett munka típusával a legelégedettebbek, ennek a két tényezőnek a megítélése közelít a nyíregyházi lakosoknál mért szinthez, bár összességében ebben a tekintetben is a telepiek elégedetlensége rajzolódik ki a Nyíregyháza Életminősége vizsgálat adataihoz képest. (13. táblázat)

A munkaerőpiaci esélyek fokozhatók egy-egy képzés, továbbképzés, átképzés segítségével. A roma, aluliskolázott csoportok rosszul megválasztott munkakeresési stratégiája, alapvető munkaerőpiaci kompetenciájának hiánya alááshatja munkakeresésük sikerességét. A piacképes szakképesítés mellett nagyon fontos a munkakeresés előszobájaként értelmezhető önéletrajz, motivációs levél elkészítésnek minősége, egy-egy állásinterjún való személyes megjelenésnek, szereplésnek a kimenetele. Az ezek eredményességét meghatározó tanfolyamok indítása fontos lépése lehet az elhelyezkedés elősegítésének. Ehhez kapcsolódóan megkérdeztük a vizsgálat alanyait, hogy hajlandóak lennének-e bekapcsolódni valamilyen képzésbe annak érdekében, hogy javuljanak a munkaerőpiaci esélyeik.

A válaszadók közel 55\%-a válaszolta azt, hogy szívesen részt venne valamilyen képzésben, egyharmaduk akár a hat hónapon túli időtartamra szóló képzéslehetőségétől sem zárkózik el. A két telep vonatkozásában nem találtunk statisztikailag releváns összefüggést ennek a kérdésnek a vonatkozásában. (14. táblázat) 


\begin{tabular}{|l|c|}
\hline Képzésben való részvétel & $\mathbf{\%}$ \\
\hline Igen, de csak rövid időtartamú néhány hónapos képzésbe & 22,1 \\
\hline Igen, akár 6 hónapot meghaladó képzésbe & 32,5 \\
\hline Nem & 45,4 \\
\hline Összesen & 100,0 \\
\hline
\end{tabular}

Forrás: Telepi kutatás 2019.

14. táblázat: A képzésbe való bekapcsolódásról alkotott vélemények megoszlása, N=204

\section{Összegzés}

Eredményeinkből a Huszártelepen és a Keleti lakótelepen élők erőteljes foglalkozatási hátránya rajzolódik ki. Az okok között köztudottan szerepet játszik a romákra jellemző iskolai végzettség alacsony szintje, a szakképzettség hiánya, a roma etnikumhoz tartozás, melyek nehezítik a munkaerőpiaci helytállást, s melyek tartós munkanélküliséget, jövedelmi szegénységet, végső esetben kirekesztődést eredményezhetnek.

A két telepen élő válaszadók egynegyede keresett munkát a megkérdezés pillanatában. A Huszártelep lakói valamivel nagyobb arányban kerestek munkát, azonban az is látható, hogy az itt élők borúlátóbbak a munkakeresés sikerességét illetően, mint a Keleti lakótelepen élők. Ezzel összefüggésben az tapasztalható, hogy a huszártelepiek talán éppen ezen okok miatt nyitottabbak a helyzetük javítását nagyobb valószínüséggel eredményező költözésre és tanulásra.

A két telepen élő foglalkoztatott romák egyharmadára az általánosnak tekinthető heti 40 órás foglalkoztatás jellemző. Ez messze elmarad a Nyíregyháza Életminősége vizsgálatban részt vevő nyíregyházi lakosokhoz képest. A telepi lakosok egyharmada közmunkaprogram keretében dolgozik. A Huszártelepen jellemzőbb a részmunkaidős foglalkoztatás, míg a határozott munkaidejü szerződéssel történő foglalkoztatás a Keleti lakótelepen élők körében gyakoribb. A legtöbben 6 hónapra és egy éves időtartamra szóló szerződéssel vannak foglalkoztatva. A rokkantságból, betegségből eredő munkaerőpiaci távolmaradás nagyságrendekkel nagyobb mértékben érinti a telepi lakosokat. A vizsgálat idején ,,nem dolgozók” közel 20\%-a az inaktivitás ezen formája miatt nem végzett fizetett munkát.

\section{Felhasznált irodalom}

1. Fábián G., Takács P., Szigeti F. (2018): Jövedelmi helyzet, jövedelmi egyenlőtlenségek. Acta Medicina et Sociologica Vol 9. No.27: 58-69. doi: 10.19055/ams.2018.9/27/5

2. Fábián G., Huszti É., Hüse L., Takács P. (2018): Az életminőség Nyíregyházán. Szabolcs-szatmár-beregi szemle, 2018/3: 83-102.

3. Fónai M., Pénzes M. (2006): A cigány népesség egészségi állapotának összetevői Északkelet-Magyarországon. In: Fónai M., Pénzes M., Vitál A. (szerk.): Et- 
nikai szegénység, etnikai egészségi állapot? A cigány népesség élethelyzete és kitörési lehetőségei Északkelet-Magyarországon. Nyíregyháza: Krúdy Könyvkiadó - Szocio East Egyesület, 75-111.

4. Jávorné Erdei R. (2016.): Nyíregyháza város lakosságának életminősége az egészségi állapot tükrében. $\mathrm{PhD}$ doktori értekezés, letöltve: http://lsp.etk.pte.hu/portal/wp/File/Doktoriiskola/Tezisfuzetek/Javorne_Erdei Renata_dissz.pdf

5. Láczay M., R. Fedor A. (é.n.): A szabolcs-szatmár-beregi határmenti fiatalok munkaerőpiaci helyzetének elemzése Köztes-Európa, VIKEK (A Virtuális Intézet Közép-Európa Kutatására), megjelenés alatt.

6. R. Fedor A. (2018): Foglalkoztatási helyzetkép és a munkával való elégedettség jellemzői. Acta Medicinae et Sociologica Vol 9. No.27: 33-57. doi: 10.19055/ams.2018.9/27/4

7. R. Fedor A., Fónai M. (2017): A magasan kvalifikált fiatal munkavállalói csoportok elemzésének új megközelítési lehetősége: a prekariátus. Különleges Bánásmód 3: 4 pp. 7-17.

8. KSH: Munkaerőpiaci helyzetkép 2014-2018, Látogatva 2019. április http://www.ksh.hu/docs/hun/xftp/idoszaki/munkerohelyz/munkerohelyz17.pdf 